\title{
Serum thyrotrophin determination on day 5 of life as screening procedure for congenital hypothyroidism
}

\author{
FRANÇOIS DELANGE, MONIQUE CAMUS, MARIANNE WINKLER, JOSÉE DODION, \\ AND ANDRÉ-MARIE ERMANS \\ From the Departments of Paediatrics and Radioisotopes, Saint-Pierre Hospital, University of Brussels, \\ Belgium
}

SUMMARY In 327 newborns cord blood thyroxine (T4) was $11 \cdot 8 \pm 0 \cdot 4 \mu \mathrm{g} / 100 \mathrm{ml}$ (SEM) $(151 \cdot 9 \pm$ $5 \cdot 1 \mathrm{nmol} / \mathrm{l}$ ), and serum thyrotrophin (TSH) $6 \cdot 7 \pm 1 \cdot 0 \mu \mathrm{U} / \mathrm{ml}$. Variability was marked for both T4 and TSH. Remeasured in the same patients on the fifth day of life, the TSH level was $3 \cdot 7 \pm 1 \cdot 0$ $\mu \mathrm{U} / \mathrm{ml}$, lower than at birth $(\mathrm{P}<0.001)$, while scattering of TSH values was much smaller, with $99.4 \%$ of values $<12 \mu \mathrm{U} / \mathrm{ml}$. TSH level at day 5 was therefore subsequently used as a screening procedure, considering $12 \mu \mathrm{U} / \mathrm{ml}$ as the upper limit of normal.

In 14 of 1805 newborns $(0.8 \%)$, the TSH level exceeded this limit; in 3 raised TSH levels were subsequently confirmed, and hypothyroidism established by conventional criteria. One was a case of lingual thyroid (TSH $>50 \mu \mathrm{U} / \mathrm{ml}$ ) and the other 2 (TSH 27 and $50 \mu \mathrm{U} / \mathrm{ml}$ ) iatrogenic caused by massive iodine impregnation of the mother (amniofetography). High TSH levels (160, 500, and $234 \mu \mathrm{U} / \mathrm{ml}$ ) were also found in 3 hypothyroid infants aged less than one month who did not belong to the present screening programme.

The striking difference between the TSH levels observed in normal and in hypothyroid infants during the first weeks of life suggests that serum TSH level at day 5 of life is the best parameter for systematic screening for congenital hypothyroidism.

Mental retardation due to congenital hypothyroidism can be avoided only if adequate replacement treatment is initiated very early, ideally during the first days of life (Smith et al., 1957; Man et al., 1963; Raiti and Newns, 1971; Klein et al., 1972; Rager et al., 1974; Dutau and Rochiccioli, 1975). Recent investigations have shown that the incidence of the disease ranges from 1 in 5000 to 1 in 10000 (Klein et al., 1974; Dussault et al., 1975b; Fisher, 1975; Walfish et al., 1975); systematic screening for congenital hypothyroidism in the newborn thus represents an important factor in the prevention of mental retardation.

A diagnosis of hypothyroidism on clinical evidence at birth is rarely possible (Lowrey et al., 1958; König, 1968; Raiti and Newns, 1971; Dutau and Rochiccioli, 1975), and it must depend therefore on biochemical evidence. The problem is that of defining the biochemical change which would be the earliest and most reliable sign of the disease in a screening programme. Dussault and Laberge (1973)

Received 17 May 1976 developed a screening technique based on radioimmunoassay of thyroxine (T4) on the 5th day of life from an eluate of dried blood. This technique was later adapted and modified by several teams (Walfish et al., 1975; Rochiccioli et al., 1975; Larsen and Broskin, 1975). Others use measurements of thyrotrophin (TSH) in cord blood (Klein et al., 1974; Walfish et al., 1975). Raised TSH has the advantage of being a far more sensitive test of thyroid insufficiency which is capable of detecting the disease in various conditions where the level of circulating hormones has not yet changed (Job et al., 1972; Shenkman et al., 1973; Hayek et al., 1973; Gordin et al., 1974; Barnes, 1975), and in particular where there is ectopic thyroid (Hamilton and Hutchison, 1975).

The object of this study was to define the optimum conditions of screening for congenital hypothyroidism by means of TSH assays. In a preliminary phase the method was selected on the basis of a comparison of TSH levels in cord blood and on day 5 of life in 327 newborns. Cord blood T4 levels were also determined in $\mathbf{2 7 3}$ of them. In the light of the 
results, we began systematic screening by determining the TSH level on day 5. The method was applied to all newborns in the maternity section of this hospital. In this report, which covers the first 1478 cases studied by this method, we have tried to define the critical threshold of TSH above which thyroid pathology may be suspected. Particular attention was paid to 14 cases showing values above this critical level, among which we detected 3 cases of congenital hypothyroidism.

\section{Patients}

A total of 1805 neonates born in this hospital over a period of 20 months were screened. The maternity section handles 1500-1700 births per year. $60 \%$ of the mothers are Belgian (Centre d'Informatique en Gynécologie et Obstétrique, Brussels, 1975, unpublished data) while the other nationalities most frequently encountered are Spanish, Italian, and Moroccan immigrants who have lived in Belgium for periods ranging from a few months to 10 years or more.

\section{Methods}

TSH level was measured by radioimmunological analysis. At the end of the reaction the fraction of TSH bound to antibody must be separated from the free fraction. In the first phase of the work this was done by the double antibody technique (Samols and Bilkus, 1964) using the CEA-IRE-SORIN (CIS) TSH Kit (method A). In a second phase separation was achieved by a technique binding the antibody to a solid phase according to Wide's method (1969) using the Phadebas TSH Kit (Pharmacia AB, Uppsala, Sweden) (method B). The upper and lower limits of sensitivity of these methods were $50 \mu \mathrm{U} / \mathrm{ml}$ and $1.5 \mu \mathrm{U} / \mathrm{ml}$, respectively. For values greater than $50 \mu \mathrm{U} / \mathrm{ml}$, the samples must first be diluted with serum containing a known low quantity of TSH $(1.5 \mu \mathrm{U} / \mathrm{ml})$. This value is taken into account when calculating the result.

The T4 level was determined by the method of Murphy and Pattee (1964). The triiodothyronine (T3) level was determined by radioimmunoassay, using the method described by Hesch and Evered (1973).

\section{Investigations}

Preliminary phase. Serum TSH and T4 were measured in the cord blood of 327 randomly-selected newborns, and TSH was remeasured in the same patients on day 5 after birth. At that time, $0.4 \mathrm{~cm}^{3}$ of whole blood was collected by heel puncture. The following information was also collected for analysis: general thyroid history of the mother before the pregnancy, course of the pregnancy, duration of periods of dilatation and expulsion, condition of the baby at birth, gestational age, sex, weight, length, T4 and TSH levels in cord blood, TSH on day 5, name and nationality of parents. A correlation was sought between each of the three biochemical measurements and the duration of dilatation, expulsion, and gestational age respectively, and also between the TSH level in the cord blood and that measured on day 5. Any differences between these results in relation to the nationality of the parents were also sought.

Systematic screening. On the basis of the results obtained above, systematic screening was undertaken by TSH determination on day 5 of life in 1478 infants born between 1 July 1974 and 14 July 1975 , i.e. $96.4 \%$ of the liveborn infants. Average age at the time of sampling was 5 days $\pm 0.5(\mathrm{SD})$. Method A was used during the preliminary phase (327 patients) and for the first 577 patients of the second phase. In the other 901 patients TSH was measured by method $B$.

For measurements in cord blood the critical level of TSH was set at $20 \mu \mathrm{U} / \mathrm{ml}$ in line with Fisher's recommendations (1973). For measurements taken on day 5 (discussed below), the threshold was arbitrarily lowered to $12 \mu \mathrm{U} / \mathrm{ml}$, both during the preliminary phase of the work and during systematic screening. Infants showing values greater than this critical level were given further tests, namely determination of serum TSH, T4, and in a few cases T3. These tests were conducted as soon as possible, together with careful clinical examinations and $x$ rays of the knee and foot to determine bone maturation. The criteria of Pyle and Hoerr (1955) were used for the knee and those of Hoerr et al. (1962) for the foot. In cases where these examinations indicated possible hypothyroidism, a thyroid scintigram was carried out immediately, using ${ }^{99} \mathrm{~m}$ Tc pertechnetate according to the technique proposed by Hayek et al. (1971) to determine the exact location and volume of the thyroid. When clinical, biochemical, and $x$-ray examinations were normal, the infants were followed up. In cases where hypothyroidism was confirmed, the infants were treated immediately with maximum doses of thyroid extracts, according to the technique of Petricciani et al. (1971) $\left(120-150 \mathrm{mg} / \mathrm{m}^{2}\right.$ per day).

As reported below, abnormal TSH values were found in 3 newborns whose mothers had undergone amniofetography. These $x$-rays had been taken 24 hours after amniocentesis and intra-amniotic injection of $30 \mathrm{ml}$ diatrizoic acid and $12 \mathrm{ml}$ iodophthalein (Lipiodol) containing $6.2 \mathrm{~g}$ iodine. Simultaneous injection of these two contrast products allows 


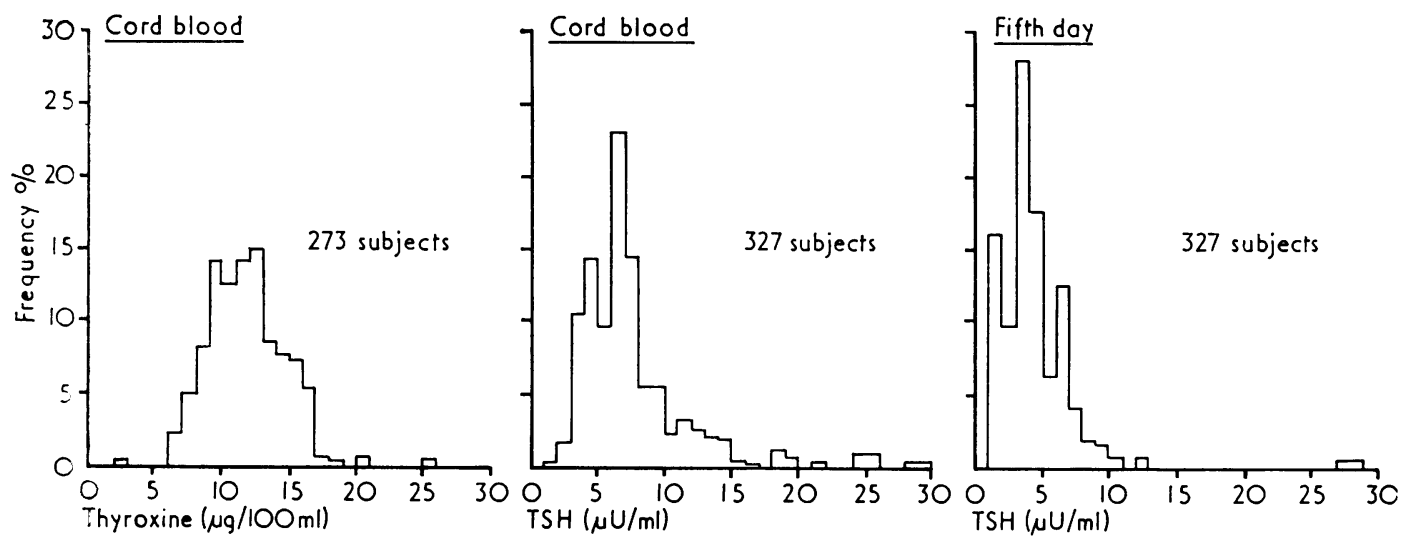

Fig. Comparison of frequency distributions of TSH values in cord blood and on day 5 of life in 327 newborns, and of T4 values in cord blood in 273 . Conversion: Traditional units to SI-Thyroxine: $1 \mu \mathrm{g} / 100 \mathrm{ml} \approx 12 \cdot 87 \mathrm{nmol} / \mathrm{l}$.

radiographic visualization of the digestive tract and fetal skin covering. The injection had been performed 24 to 48 hours before delivery.

\section{Results}

The Fig. shows the distribution of TSH levels in the cord blood and on day 5 in the 327 newborns, and of T4 levels in cord blood in 273 of them. The distribution of T4 values in the cord blood is symmetrical, mean $11 \cdot 8 \pm 0 \cdot 4 \mu \mathrm{g} / 100 \mathrm{ml}(151 \cdot 9 \pm 5 \cdot 1 \mathrm{nmol} / \mathrm{l})$ (SEM). TSH levels measured at the same time show a distinctly asymmetrical distribution, with a marked spread of results towards high values. The geometrical mean of TSH values in the cord blood is $6 \cdot 7 \pm 1 \cdot 0 \mu \mathrm{U} / \mathrm{ml}$ (SEM). TSH values on day 5 are less variable, and the asymmetry towards high values is much less pronounced than for cord blood. The geometrical mean is $3.7 \pm 1.0 \mu \mathrm{U} / \mathrm{ml}$ (SEM), significantly lower than that at birth $(P<0.001)$.

Distinctly abnormal values for cord $\mathrm{T} 4$ were shown in 2 infants. In the first, the value was $2 \cdot 1 \mu \mathrm{g} / 100 \mathrm{ml}(27 \mathrm{nmol} / \mathrm{l})$, whereas $\mathrm{T} 3$ resin uptake exceeded $160 \%$ and the thyroxine-binding-globulin (TBG) saturation capacity was $17 \mu \mathrm{g}$ thyroxineiodine $/ 100 \mathrm{ml}(1340 \mathrm{nmol} / \mathrm{l}) ; \mathrm{TSH}$ was $2 \cdot 2 \mu \mathrm{U} / \mathrm{ml}$. These results suggest a partial congenital deficiency of TBG. In the second infant the T4 level was 24.6 $\mu \mathrm{g} / 100 \mathrm{ml}(317 \mathrm{nmol} / \mathrm{l})$, showing no clinical signs of hyperthyroidism. No further tests could be done.

For cord blood TSH, 9 infants showed values greater than $20 \mu \mathrm{U} / \mathrm{ml}$. The results are given in Table 1. In 5 cases expulsion had lasted more than an hour and in 1 case had necessitated use of a vacuum extractor. In another pre-eclampsia occurred at the end of the pregnancy. The T4 levels measured in 8 out of 9 patients were normal and control TSH measurements on day 5 were all normal. For TSH levels on day $5,99 \cdot 4 \%$ of the results lay below $12 \mu \mathrm{U} / \mathrm{ml}$, which is why this value was regarded as the critical threshold. Results greater than this were obtained in 4 patients (discussed below).

Table 2 gives the correlation coefficients for T4 and TSH levels in the cord blood and for TSH on day 5 and duration of dilatation, duration of expulsion, and gestational age. There was no significant

Table 1 Control TSH levels on day 5 of life in the 9 out of $327(3 \%)$ infants who had had cord blood TSH levels of $20 \mu \mathrm{U} / \mathrm{ml}$ or more

\begin{tabular}{|c|c|c|c|}
\hline \multirow{2}{*}{ Case no. } & \multicolumn{2}{|l|}{ Cord blood } & \multirow{2}{*}{$\frac{\text { Control day } 5}{T S H(\mu U / m l)}$} \\
\hline & $T S H(\mu U / m l)$ & $T 4 \mu \mathrm{g} / 100 \mathrm{ml}(\mathrm{nmol} / \mathrm{l})$ & \\
\hline
\end{tabular}


Table 2 Correlations between biochemical parameters measured at birth and on day 5, and the durations of cervical dilatation and expulsion from uterus, and gestational age in 273 infants

\begin{tabular}{lcl}
\hline Parameters & $\begin{array}{l}\text { Coefficient of } \\
\text { correlation }\end{array}$ & Significance \\
\hline Cord TSH-duration dilatation & -0.034 & NS \\
Cord TSH-duration expulsion & 0.033 & NS \\
Cord T4-duration dilatation & -0.064 & NS \\
Cord T4-duration expulsion & 0.041 & NS \\
Cord TSH-gestational age & -0.013 & NS \\
5th day TSH-gestational age & -0.054 & NS \\
Cord T4-gestational age & 0.159 & P $<0.01$ \\
Cord TSH-TSH on day 5 & 0.309 & $\mathrm{P}<0.001$ \\
\hline
\end{tabular}

correlation between these parameters except between T4 in cord blood and gestational age $(r=$ $0.159, \mathrm{P}<0.01)$ and TSH in cord blood and on day $5(r=0 \cdot 309, P<0 \cdot 001)$. No significant differences were observed in the parameters of Belgian, Spanish $(P>0 \cdot 6)$, Italian $(P>0 \cdot 6)$, and Moroccan $(P>0 \cdot 2)$ newborns.

Systematic screening. 1478 newborns were screened, representing $96.4 \%$ of births in the maternity section during the 20 months of the study. The average value of TSH in 577 patients using method $\mathrm{A}$, as in the preliminary phase, was $4 \cdot 2 \pm 1 \cdot 0$ $\mu \mathrm{U} / \mathrm{ml}$ (SEM). The value obtained in 901 patients according to method $\mathrm{B}$ was $1 \cdot 7 \pm 1 \cdot 0 \mu \mathrm{U} / \mathrm{ml}$ (SEM), i.e. significantly lower $(P<0 \cdot 001)$. Despite this difference in the mean values, we kept the critical threshold at $12 \mu \mathrm{U} / \mathrm{ml}$ because values below this level were observed in $99 \cdot 3 \%$ and $99 \cdot 2 \%$ of the cases, respectively, for both methods used; the corresponding value obtained during the preliminary phase was $99.4 \%$.

Fourteen out of the 1805 infants studied $(0.8 \%$ of the cases) showed TSH values on day 5 greater than $12 \mu \mathrm{U} / \mathrm{ml}$ and were tested further, as described above. The data are summarized in Table 3. TSH on day 5 ranged from 12.5 to $>50 \mu \mathrm{U} / \mathrm{ml}$. The age of the infants at the time of the control tests ranged between 9 and 68 days, 11 of them being less than 28 days.

These tests gave normal results in 11 out of 14 infants. These infants were followed-up for 1 to 12 months. None exhibited any further thyroid problem. In one (Case 23) the additional tests showed a lingual thyroid: on day 5 of life this infant had a TSH level greater than $50 \mu \mathrm{U} / \mathrm{ml}$. Subsequent analyses of cord blood showed TSH $15.5 \mu \mathrm{U} / \mathrm{ml}$; T4 $16 \cdot 8 \mu \mathrm{g} / 100 \mathrm{ml}(216 \mathrm{nmol} / \mathrm{l}) ; \mathrm{T} 340 \mathrm{ng} / 100 \mathrm{ml}$. At 21 days of age clinical and $x$-ray examinations were normal, as were T4 levels $(8.7 \mu \mathrm{g} / 100 \mathrm{ml}$; $112 \mathrm{nmol} / \mathrm{l})$ and T3 $(210 \mathrm{ng} / 100 \mathrm{ml})$. However, TSH was still high $(50 \mu \mathrm{U} / \mathrm{ml})$. Thyroid scintigram showed an ectopic thyroid located at the base of the tongue. The infant was treated with thyroid extracts from the 32nd postnatal day. TSH reverted to normal in a few days and clinical and biochemical findings were still normal at the age of 8 months. It is obvious that in this particular case thyroid extracts should be given life long.

The last 2 patients (Cases 10 and 22) had TSH values of 27 and $50 \mu \mathrm{U} / \mathrm{ml}$ respectively on day 5 .

Table 3 Findings in 14 of 1805 patients having TSH levels $>12 \mu U / \mathrm{ml}$ on day 5

\begin{tabular}{|c|c|c|c|c|c|c|c|c|}
\hline \multirow[b]{2}{*}{ Case no. } & \multirow[b]{2}{*}{$\begin{array}{l}T S H \text { day } 5 \\
(\mu U / m l)\end{array}$} & \multicolumn{7}{|c|}{ Control data } \\
\hline & & $\begin{array}{l}\text { Age } \\
(d)\end{array}$ & $\begin{array}{l}\text { Clinical } \\
\text { signs }\end{array}$ & $\begin{array}{l}\text { Bone } \\
\text { age }\end{array}$ & $\begin{array}{l}T S H \\
(\mu U / m l)\end{array}$ & $\begin{array}{l}T 4 \\
\mu \mathrm{g} / 100 \mathrm{ml} \\
(\mathrm{nmol} / \mathrm{l})\end{array}$ & $\begin{array}{l}\text { Thyroid } \\
\text { scintigram }\end{array}$ & Remarks \\
\hline 10 & $27 \cdot 0$ & 9 & $\begin{array}{l}\text { Apathy, } \\
\text { jaundize }\end{array}$ & $\mathbf{N}$ & $14 \cdot 7$ & $14 \cdot 8(190)$ & $\mathbf{N}$ & $\begin{array}{l}\text { Amniofetography; } \\
\text { treatment from } \\
\text { day } 13\end{array}$ \\
\hline 11 & $13 \cdot 8$ & 68 & $\mathbf{N}$ & $\bar{x}$ & $3 \cdot 7$ & $8 \cdot 1(104)$ & 一 & \\
\hline 12 & $21 \cdot 6$ & 9 & $\mathbf{N}$ & $\mathbf{N}$ & $4 \cdot 1$ & $11 \cdot 2(144)$ & 一 & \\
\hline 13 & $13 \cdot 8$ & 30 & $\mathbf{N}$ & $\longrightarrow$ & $5 \cdot 1$ & - & - & \\
\hline 14 & $21 \cdot 0$ & 13 & $\mathbf{N}$ & $\mathbf{N}$ & $8 \cdot 9$ & - & 一 & \\
\hline 15 & $12 \cdot 5$ & 41 & $\mathbf{N}$ & $\mathbf{N}$ & $2 \cdot 0$ & - & - & \\
\hline 16 & $18 \cdot 0$ & 27 & $\mathbf{N}$ & $\mathbf{N}$ & $3 \cdot 2$ & - & - & \\
\hline 17 & $36 \cdot 5$ & 17 & $\mathbf{N}$ & $\mathbf{N}$ & $5 \cdot 8$ & $7 \cdot 0(90)$ & 一 & Amniofetography \\
\hline 18 & $27 \cdot 0$ & 18 & $\mathbf{N}$ & $\overline{1}$ & 1.9 & $9 \cdot 0(116)$ & 一 & \\
\hline 19 & $13 \cdot 5$ & 14 & $\mathbf{N}$ & $\mathbf{N}$ & $1 \cdot 5$ & - & - & \\
\hline 20 & $14 \cdot 0$ & $\bar{n}$ & $\mathbf{N}$ & - & $2 \cdot 3$ & - & - & \\
\hline $\begin{array}{l}21 \\
22\end{array}$ & $\begin{array}{l}23 \cdot 5 \\
50 \cdot 0\end{array}$ & $\begin{array}{l}25 \\
16\end{array}$ & $\stackrel{\mathbf{N}}{\text { Goitre }}$ & $\mathbf{N}$ & $\begin{array}{c}1.0 \\
-250\end{array}$ & $\overline{3}, 2,41)$ & $\overline{1}$ & \\
\hline & & 16 & Goltre & $\mathbf{N}$ & $>250$ & $3 \cdot 2(41)$ & Large goitre & $\begin{array}{l}\text { Amniofetography; } \\
\text { treatment from } \\
\text { day } 23\end{array}$ \\
\hline 23 & $>50.0$ & 21 & $\mathbf{N}$ & $\mathbf{N}$ & 50 & $8 \cdot 7(112)$ & $\begin{array}{l}\text { Lingual } \\
\text { thyroid }\end{array}$ & $\begin{array}{l}\text { Treatment from } \\
\text { day } 32\end{array}$ \\
\hline
\end{tabular}


Case 10 presented apathy and extremely slow sucking on the 9th day. TSH was then still high (14.7 $\mu \mathrm{U} / \mathrm{ml}) ; \mathrm{T} 4$ and thyroid scintigram were normal. Case 22 at the age of 16 days presented clinically apparent thyroid hyperplasia, confirmed by thyroid scintigram. TSH at that point was greater than 250 $\mu \mathrm{U} / \mathrm{ml}$ and $\mathrm{T} 4 \mathrm{had}$ fallen to $3 \cdot 2 \mu \mathrm{g} / 100 \mathrm{ml}(41$ nmol/1). These 2 infants were also treated with thyroid extracts and their clinical and biochemical signs rapidly returned to normal. Treatment was withdrawn after 23 and 16 days respectively. Further controls for TSH and T4 in serum gave normal values. It is particularly significant that the mothers of these 2 infants had each undergone amniofetography on the day before their delivery. The same examination had been performed 2 days before delivery on the mother of Case 17 whose TSH had reached $36 \cdot 5 \mu \mathrm{U} / \mathrm{ml}$ on day 5 but reverted to normal spontaneously on day 17.

During these investigations diagnosis of congenital hypothyroidism was confirmed in 3 other infants, aged 26, 27, and 3 days, who had been sent to the paediatric department with probable diagnosis of thyroid insufficiency based on clinical evidence. The first 2 presented lingual thyroids, the third a probable metabolic goitre with hypothyroidism and no signs of iodine impregnation. TSH levels were 160,500 , and $234 \mu \mathrm{U} / \mathrm{ml}$ respectively, and T4 $2 \cdot 4,3 \cdot 0$, and $7 \cdot 2 \mu \mathrm{g} / 100 \mathrm{ml}(31,39,93 \mathrm{nmol} / \mathrm{l})$ respectively.

\section{Discussion}

The results indicate that determination of serum TSH level on day 5 of life is an eminently suitable technique for detecting congenital hypothyroidism in the newborn. Contrary to what is observed at birth, the variability of individual results on the 5th day is small. The sensitivity of the method is confirmed by the substantial deviation observed between the normal mean, i.e. $1 \cdot 7 \pm 1 \cdot 0 \mu \mathrm{U} / \mathrm{ml}$ (method B), and the pathological cases for which the values obtained were 15-50 times higher.

The controversial question is whether raised TSH alone constitutes sufficient evidence on which to base a diagnosis of hypothyroidism and to justify treatment (Hershman and Pittman, 1971; Ikram et al., 1973; Evered et al., 1973; Jackson et al., 1975). A moderate, but sometimes substantial, increase in TSH has been observed in the initial stage of development of a goitre regarded as euthyroid, either idiopathic (Young et al., 1975) or due to iodine deficiency (see review in Delange, 1974). In the latter condition a state of thyroid compensation can be maintained by permanently increased thyrotrophic stimulation. Various, perhaps transient, conditions can cause increased TSH in the newborn (Fisher and Sack, 1975) and do not necessarily imply hypothyroidism leading to mental retardation. However, out of the 14 abnormal TSH values observed on day 5 in these infants, 3 infants were still abnormal at the time of subsequent control examinations and 2 of these presented definite thyroid pathologies, namely lingual thyroid and goitre with hypothyroidism. Furthermore, various authors have reported raised TSH values in a number of conditions leading to thyroid insufficiency before any perceptible drop in the level of thyroid hormones or any clinical signs have been noted (Job et al., 1972; Hayek et al., 1973; Gordin et al., 1974). In this respect, raised TSH is one of the important biochemical indications of a state of premyxoedema (Ikram et al., 1973) or compensated hypothyroidism (Hayek et al., 1973; Barnes, 1975) which may develop into definite hypothyroidism, therefore justifying treatment with thyroid extracts (Hayek et al., 1973; Ikram et al., 1973; Evered et al., 1973; Young et al., 1975; Barnes, 1975; Rallison et al., 1975; Herrmann et al., 1975). The rise in TSH is an indicator whose sensitivity and specificity are useful for systematic screening.

As several authors have suggested (Klein et al., 1974; Fisher, 1975; Walfish et al., 1975), the sensitivity of the TSH method seems to give it a decisive advantage over screening based on T4 determination (Dussault et al., 1975b): the measurement of T4 undoubtedly offers considerable advantage from the public health view, especially its low cost and the possibility of performing the assay in an eluate of dried blood. However, the cases of hypothyroidism reported here confirm the view (Fisher and Sack, 1975) that myxoedema can be accompanied by no more than slightly abnormal serum T4 levels in the newborn. This was so with the infant with the lingual thyroid, in whom TSH on day 5 was, in contrast, distinctly increased. This newborn would have escaped detection based on T4 measurements on day 5 of life, or a method based on cord TSH. As recently underlined by Fisher and Sack (1975), this point is particularly important in the detection of congenital hypothyroidism because the most frequent cause of this disease is thyroid dysgenesis (Neimann et al., 1958; Little et al., 1965; Dutau and Rochiccioli, 1975) in which the thyroid deficit is only partial. The greater sensitivity of the TSH method is also confirmed by the study of the 3 cases of clinically detectable hypothyroidism in which, as other authors have reported (Dutau and Rochiccioli, 1975; Dussault et al., 1975b; Jackson et al., 1975), deviations of TSH levels from the normal mean were much more pronounced than those of T4. 
The main disadvantages of screening based on TSH measurement are its fairly high cost and the fact that it has hitherto required a whole blood sample. The cost may be affected substantially by a number of factors, but it is obvious that 5000-10000 TSH analyses cost substantially less than society pays out for the care of a gravely mentally handicapped person over several decades. The problem of TSH elution from a whole blood sample collected on paper is currently being investigated in a number of laboratories (Dussault et al., 1975a; Foley et al., 1975), including our own. We cannot preclude the possibility that subjects with normal serum TSH, or T4 concentrations on day 5, would not develop hypothyroidism later on. Further studies are necessary to clarify this point.

Our results concerning the distribution of T4 and TSH levels in the cord blood confirm results reported by other authors (see review in Similä et al., 1975). Our findings do not confirm the relationship hypothesized by Walfish et al. (1975) between the level of TSH in the cord and the duration of the delivery. However, in view of the lack of any major obstetrical pathologies in our series of cases, this hypothesis is not ruled out. The correlation observed between the level of T4 in the cord blood and the gestational age of the baby ties in with the findings of others (Fisher et al., 1970; Greenberg et al., 1970) who have reported a progressive increase in the level of T4 during fetal growth.

The rise in TSH in the 3 newborns whose mothers had undergone amniofetography at the end of their pregnancies ties in with a similar observation reported by Bühler et al. (1973). The presence of a moderately increased (Case 10) or substantially increased (Case 22) TSH level with a normal or low T4 level associated with thyroidal hyperplasia after the administration of large doses of iodine to the mother suggests a partial blockage of organification due to a Wolff-Chaikoff effect (Wolff and Chaikoff, 1948). But this does not account for the fact that, paradoxically, the thyroid glands of these infants trap sufficient technetium to allow visualization of the gland, whereas this is not the case in severe iodine contamination. The possibility of a pre-existent anomaly of thyroid metabolism cannot be ruled out in our 3 patients since the follow-up period is not yet long enough to allow a definite answer to this question. The strong thyrotrophic stimulation observed in newborns whose mothers had undergone amniofetography calls for thorough investigation. In any event, it seems that the thyroids of such newborns should be tested systematically shortly after birth in order to test whether this investigation is safe (Amy and Mandelman, 1973).
In conclusion, our investigations strongly suggest that the level of TSH measured on the 5th day of life is a suitable parameter for systematic screening for hypothyroidism in newborns. The prospect of combining this method with screening for aminoacidopathies in whole blood sampled on paper is of major practical interest. It is still too early to fix a critical level of TSH which would reliably indicate thyroid pathology in the newborn. On the basis of a critical threshold of $12 \mu \mathrm{U} / \mathrm{ml}$, our investigations showed 14 abnormal values in a total of 1805 cases, of which only 3 were confirmed by subsequent examinations. Using the threshold value of 20 $\mu \mathrm{U}$ proposed by Fisher (1973) the number of abnormal values would be reduced to 8 , or $0.4 \%$, and would include the 3 cases of confirmed hypothyroidism. The threshold of $20 \mu \mathrm{U} / \mathrm{ml}$ therefore seems reasonable, but remains to be confirmed.

We thank Mrs. C. Branders and F. Dubois for technical assistance; Mrs. M. Dramaix and Miss L. Ramioul for statistical analysis of the data; Dr. R. Wolter, Dr. F. Rodesch, and the nurses of the Maternity Section for their clinical help; and Professors H. L. Loeb and P. O. Hubinont for encouragement and support. This work was supported in part by 'Fonds de la Recherche Scientifique Médicale' (Belgium) and by Contract of the Ministère de la Politique Scientifique (Belgium) within the frame work of the Association EuratomUniversity of Brussels-University of Pisa.

\section{References}

Amy, J. J., and Mandelman, N. (1973). Fetography: technique and applications. European Journal of Obstetrics, Gynecology and Reproductive Biology, 3, 25-30.

Barnes, N. D. (1975). Serum TSH measurement in children with thyroid disorders. Archives of Disease in Childhood, 50, 497-499.

Bühler, U. K., Girard, J., and Stalder, G. (1973). Congenital iodide goitre and hypothyroidism due to intrauterine application of iodine-containing contrast medium. Acta Paediatrica Scandinavica, 62, 108-109.

Delange, F. (1974). Endemic Goitre and Thyroid Function in Central Africa. Monographs in Pediatrics No. 2. Karger, Basle.

Dussault, J. H., and Laberge, C. (1973). Dosage de la thyroxine (T4) par méthode radioimmunologique dans l'éluat de sang séché: nouvelle methode de dépistage de l'hypothyroïdie néonatale? L'Union Médicale du Canada, 102, 2062-2064.

Dussault, J. H., Coulombe, P., and Laberge, C. (1975a). Neonatal thyroid screening. Perinatal Thyroid Physiology and Disease, p. 221. Ed. by D. A. Fisher and G. N. Burrow. Raven Press, New York.

Dussault, J. H., Coulombe, P., Laberge, C., Letarte, J., Guyda, H., and Khoury, K. (1975b). Preliminary report on a mass screening program for neonatal hypothyroidism. Journal of Pediatrics, 86, 670-674.

Dutau, G., and Rochiccioli, P. (1975). Les dysgénésies thyroidiennes. A propos de 63 observations. Annales de Pédiatrie, 22, 315-325. 
Evered, D. C., Ormston, B. J., Smith, P. A., Hall, R., and Bird, T. (1973). Grades of hypothyroidism. British Medical Journal, 1, 657-662.

Fisher, D. A. (1973). Advances in the laboratory diagnosis of thyroid disease. Part II. Journal of Pediatrics, 82, 187-191.

Fisher, D. A. (1975). Neonatal detection of hypothyroidism. Journal of Pediatrics, 86, 822-824.

Fisher, D. A., and Sack, J. (1975). Thyroid function in the neonate and possible approaches to newborn screening for hypothyroidism. Perinatal Thyroid Physiology and Disease, p. 197. Ed. by D. A. Fisher and G. N. Burrow. Raven Press, New York.

Fisher, D. A., Hobel, C. J., Garza, R., and Pierce, C. A. (1970). Thyroid function in the preterm fetus. Pediatrics, 46, 208-216.

Foley, T. P., Klein, A. H., Agustin, A. V., and Hopwood, N. J. (1975). Screening for congenital hypothyroidism by the determination of thyrotropin levels. Perinatal Thyroid Physiology and Disease, p. 255. Ed. by D. A. Fisher and G. N. Burrow. Raven Press, New York.

Gordin, A., Saarinen, P., Pelkonen, R., and Lamberg, B. A. (1974). Serum thyrotrophin and the response to thyrotrophin releasing hormone in symptomless autoimmune thyroiditis and in borderline and overt hypothyroidism. Acta Endocrinologica, 75, 274-285.

Greenberg, A. H., Czernichow, P., Reba, R. C., Tyson, J., and Blizzard, R. M. (1970). Observations on the maturation of thyroid function in early fetal life. Journal of Clinical Investigation, 49, 1790-1803.

Hamilton, W., and Hutchison, J. H., (1975). Raised serum TSH in hypothyroidism. Archives of Disease in Childhood, 50, 567-569.

Hayek, A., Bauman, R. A., and Crawford, J. D. (1971). $99^{\mathrm{m}}$ TC pertechnetate for detection of cryptic thyroid tissue in childhood hypothyroidism. Journal of Pediatrics, 79, 466-468.

Hayek, A., Maloof, F., and Crawford, J. D. (1973). Thyrotropin behavior in thyroid disorders of childhood. Pediatric Research, 7, 28-38.

Herrmann, J., Schaps, D., Rusche, H. J., Berger, M., Krüskemper, H. L., Mühlen, A. von zur, Hackenberg, K., and Reinwein, D. (1975). Serum triiodothyronine 7-15 years after fractionated low dose radioiodine therapy of thyrotoxicosis. Clinical Endocrinology, 4, 205-212.

Hershman, J. M., and Pittman, J. A. (1971). Control of thyrotropin secretion in man. New England Journal of Medicine, 285, 997-1006.

Hesch, R. D., and Evered, D. (1973). Radioimmunoassay of triiodothyronine in unextracted human serum. British Medical Journal, 1, 645-648.

Hoerr, N. L., Pyle, S. I., and Francis, C. C. (1962). Radiographic Atlas of Skeletal Development of the Foot and Ankle. Thomas, Springfield, Ill.

Ikram, H., Banim, S., and Fowler, P. B. S. (1973). Diagnostic index for premyxoedema. Lancet, 2, 1405-1408.

Jackson, D., Vanderschueren-Lodeweyckx, M., and Grant, D. B. (1975). Thyrotropin estimation in diagnosis and treatment of childhood thyroid disorders. Archives of Disease in Childhood, 50, 522-525.

Job, J. C., Binet, E., Canlorbe, P., and Rossier, A. (1972). Traitement des hypothyroidies de l'enfant. Valeur du taux sérique de la thyréostimuline. Nouvelle Presse Médicale, 1, 305-308.

Klein, A. H., Meltzer, S., and Kenny, F. M. (1972). Improved prognosis in congenital hypothyroidism treated before age three months. Journal of Pediatrics, 81, 912-915.

Klein, A. H., Agustin, A. V., and Foley, T. P. (1974). Successful laboratory screening for congenital hypothyroidism. Lancet, $2,77-79$.
König, M. P. (1968). Die Kongenitale Hypothyreose und der Endemische Kretinismus, p. 52. Springer, Berlin.

Larsen, P. R., and Broskin, K. (1975). Thyroxine (T4) immunoassay using filter paper blood samples for screening of neonates for hypothyroidism. Pediatric Research, 9, 604-609.

Little, G., Meador, C. K., Cunningham, R., and Pittman, J. A. (1965). 'Cryptothyroidism', the major cause of sporadic 'athyreotic' cretinism. Journal of Clinical Endocrinology and Metabolism, 25, 1529-1536.

Lowrey, G. H., Aster, R. H., Carr, E. A., Ramon, G., Beierwaltes, W. H., and Spafford, N. R. (1958). Early diagnostic criteria of congenital hypothyroidism: a comprehensive study of forty-nine cretins. American Journal of Diseases of Children, 96, 131-143.

Man, E. B., Mermann, A. C., and Cooke, R. E. (1963). The development of children with congenital hypothyroidism. Journal of Pediatrics, 63, 926-941.

Murphy, B. E. P., and Pattee, C. J. (1964). Determination of thyroxine utilizing the property of protein-binding. Journal of Clinical Endocrinology and Metabolism, 24, 187-196.

Neimann, N., Kellershohn, C., Pierson, M., and Martin, J. (1958). Le rôle de l'ectopie thyroïdienne dans la génèse du myxoedème. Archives Françaises de Pédiatrie, 15, 315-342.

Petricciani, J. C., Aceto, T., McGillivray, M. H., and Wagner, H. (1971). Treatment of young cretins with triiodothyronine. Metabolism, 20, 678-680.

Pyle, S. I., and Hoerr, N. L. (1955). Radiographic Atlas of Skeletal Development of the Knee. Thomas, Springfield, Ill.

Rager, K., Ranke, M., Bierich, J. R., Blüthmann, S., and Hoss, W. (1974). Köperliche und geistige Entwicklung hypothyreoter Kinder unter Therapie mit syntetischen Schildrüsenhormonen. Deutsche Medizinische Wochenschrift, 99, 2497-2502.

Raiti, S., and Newns, G. H. (1971). Cretinism: early diagnosis and its relation to mental prognosis. Archives of Disease in Childhood, 46, 692-694.

Rallison, M. L., Dobyns, B. M., Keating, F. R., Rall, J. E., and Tyler, F. H. (1975). Occurrence and natural history of chronic lymphocytic thyroiditis in childhood. Journal of Pediatrics, 86, 675-682.

Rochiccioli, P., Dutau, G., Bayard, F., and Augier, D. (1975). Neonatal detection of hypothyroidism by radioimmunoassay of the thyroxin in the eluate of dried blood. Pediatric Research, 9, 685.

Samols, E., and Bilkus, D. (1964). A comparison of insulin immunoassays. Proceedings of the Society for Experimental Biology and Medicine, 115, 79-84.

Shenkman, L., Mitsuma, T., and Hollander, C. S. (1973). Methods for detection of incipient primary hypothyroidism: a comparative study. Journal of Clinical Endocrinology and Metabolism, 36, 1074-1078.

Similä, S., Koivisto, M., Ranta, T., Leppäluoto, J., Reinilä, M., and Haapalahti, J. (1975). Serum tri-iodothyronine, thyroxine, and thyrotrophin concentrations in newborns during the first two days of life. Archives of Disease in Childhood, 50, 565-567.

Smith, D. W., Blizzard, R. M., and Wilkins, L. (1957). The mental prognosis in hypothyroidism of infancy and childhood. A review of 128 cases. Pediatrics, 19, 1011-1022.

Walfish, P. G., O'Donnell, J., Ulbright, T., Shachter, G., and Frankl, A. (1975). Screening for neonatal hypothyroidism: comparison of neonatal dried capillary blood thyroxine (T4) to cord serum T4 and thyrotropin (TSH). Thyroid Research 1975, p. 601. Ed. by F. J. G. Ebbing and I. W. Henderson. Excerpta Medica, Amsterdam. 
Wide, L. (1969). Radioimmunoassays employing immunosorbents. Acta Endocrinologica, Suppl. 142, 207-221.

Wolff, J., and Chaikoff, I. L. (1948). The inhibitory action of excessive iodine upon the synthesis of diiodotyrosine and of thyroxine in the thyroid gland of the normal rat. Endocrinology, 43, 174-179.

Young, R. L., Harvey, W. C., Mazzaferri, E. L., Reynolds, J. C., and Hamilton, C. R. (1975). Thyroid-stimulating hormone levels in idiopathic euthyroid goiter. Journal of Clinical Endocrinology and Metabolism, 41, 21-26.

Correspondence to Dr. F. Delange, Dept. of Radioisotopes, Hôpital Saint-Pierre, 322, rue Haute, 1000-Brussels, Belgium.

\section{Addendum}

While this paper was being prepared, Klein et al. (1976) confirmed the sensitivity of the TSH test, but Dussault et al. (1976) showed that TSH was normal in 3 out of 28 cases of neonatal hypothyroidism detected on the basis of decreased T4, i.e. in 10 to $15 \%$ of the cases. The possibility thus arises that screening based on TSH assay could result in 'false negatives', especially in pituitary or hypothalamic hypothyroidism. As the present report indicates that T4 screening could result in 'false negatives' in primary hypothyroidism, the systematic measurement of both T4 and TSH during the first days of life as proposed by Buist et al. (1975) should be seriously considered.

\section{References}

Buist, N. R. M., Murphey, W. F., Brandon, G. R., Foley, T. P. Jr., and Penn, R. L. (1975). Neonatal screening for hypothyroidism. Lancet, 2, 872-873.

Dussault, J. H., Letarte, J., Guyda, H., and Laberge, C. (1976). Thyroid function in neonatal hypothyroidism. Journal of Pediatrics, 89, 541-544.

Klein, A. H., Foley, T. P. Jr., Larsen, R., Agustin, A. V., and Hopwood, N. J. (1976). Neonatal thyroid function in congenital hypothyroidism. Journal of Pediatrics. 89, 545-549. 